\title{
Large-Scale Atmospheric Circulation Variability and Its Climate Impacts
}

\author{
Bin $\mathrm{Yu}^{1, *(1)}$ and Anthony R. Lupo ${ }^{2}$ (I) \\ Climate Research Division, Environment and Climate Change Canada, Toronto, ON M3H5T4, Canada \\ 2 Atmospheric Science Program, School of Natural Resources, University of Missouri, \\ Columbia, MO 65211, USA; lupoa@missouri.edu \\ * Correspondence: bin.yu@canada.ca
}

Received: 13 June 2019; Accepted: 15 June 2019; Published: 18 June 2019

This special issue collects original and review articles on large-scale atmospheric circulation variability and its climate impacts. Large-scale atmospheric circulation variability can often be characterized by teleconnection patterns, which feature circulation anomalies related to each other at large distances. Teleconnections and their related circulation anomalies are forced externally or by slow internal climate dynamics, and there is growing confidence that these can be forecasted even beyond the well-known 10-14 day dynamic forecasting wall. Anomalous atmospheric circulations influence temperature and precipitation fields, the two most important climate elements. Thus, it is of great consequence to explore atmospheric circulation variability, its formation and maintenance mechanisms, and its climate impacts.

Papers in this issue consist of three main topics. Papers 1-6 present linkages between large-scale atmospheric teleconnection patterns and climate anomalies over Asia, Europe, and North America. Li et al. [1] linked large-scale circulation patterns to a long-lived heatwave in China during the summer of 2018. Chen and Song [2] studied the influence of the winter Arctic Oscillation and Siberian High on Southeast Asian surface temperature variations. Wei et al. [3] investigated the evolution of the South Asian high and its role in the onset process of the Asian summer monsoon during the spring-to-summer transition. Wang et al. [4] studied winter weather regimes in Southeastern China and their relationships with precipitation and teleconnections. Lebedeva et al. [5] explored changes in the Northern Hemisphere atmospheric circulation conditions and climatic characteristics in two remote regions (Southwest Russia and Central USA). Yu et al. [6] compared the surface temperature anomalies and their field robustness and temperature extremes over North America in association with various atmospheric teleconnection patterns.

Papers 7-12 explore sea surface temperature (SST) forcings, particularly those associated with the tropical El Niño-Southern Oscillation (ENSO), on atmospheric circulation and climate anomalies over various regions across the globe. Myoung et al. [7] studied the impacts of Pacific SSTs on atmospheric circulations leading to winter precipitation variability in California. Ye and $\mathrm{Wu}$ [8] compared ENSO impacts on the interannual runoff variations between the upper and mid-low Yangtze River watersheds and the underlying mechanism for variability. Fang et al. [9] explored the impacts of the onset time of El Niño events on summer rainfall over Southeastern Australia over the past four decades. Hou et al. [10] studied interdecadal variations in the Walker circulation and the connection to inhomogeneous air temperature changes at low latitudes from 1961 to 2012. Huang et al. [11] studied key parameter-related physical mechanisms in simulating the Madden-Julian Oscillation (MJO) in a climate system model and highlighted the role of moisture-shallow convection feedback in the MJO dynamics. Ning et al. [12] numerically investigated the variability and SST forcing mechanisms for megadroughts occurring over Eastern China during the last millennium.

Papers 13-14 review the ENSO related atmosphere-ocean forcing outside the tropical Pacific and the methods to observe the vertical exchange flux between the atmosphere boundary layer and free 
troposphere. Chen et al. [13] reviewed the contribution of the atmosphere-ocean forcings over the extratropical North Pacific, Atlantic, and Indian Ocean as well as the extratropical atmospheric forcings over the Northern and Southern Hemispheres on the ENSO occurrence. Zhang et al. [14] reviewed several methods for the quantitative measurements of the substance and energy exchange between the atmosphere boundary layer and free troposphere.

We are very thankful to our colleagues for their invaluable contributions and the reviewers for constructive comments and suggestions that helped to improve the papers. We thank the editing office for their excellent support in processing and publishing this issue.

Conflicts of Interest: The authors declare no conflict of interest.

\section{References}

1. Li, M.; Yao, Y.; Luo, D.; Zhong, L. The linkage of the large-scale circulation pattern to a long-lived heatwave over Mideastern China in 2018. Atmosphere 2019, 10, 89. [CrossRef]

2. Chen, S.; Song, L. Recent strengthened impact of the winter Arctic Oscillation on the Southeast Asian surface air temperature variation. Atmosphere 2019, 10, 164. [CrossRef]

3. Wei, W.; Wu, Y.; Yang, S.; Zhou, W. Role of the South Asian high in the onset process of the Asian summer monsoon during spring-to-summer transition. Atmosphere 2019, 10, 239. [CrossRef]

4. Wang, Y.; Jin, S.; Sun, X.; Wang, F. Winter weather regimes in Southeastern China and its intraseasonal variations. Atmosphere 2019, 10, 271. [CrossRef]

5. Lebedeva, M.G.; Lupo, A.R.; Chendev, Y.G.; Krymskaya, O.V.; Solovyev, A.B. Changes in the atmospheric circulation conditions and regional climatic characteristics in two remote regions since the mid-20th century. Atmosphere 2019, 10, 11. [CrossRef]

6. Yu, B.; Lin, H.; Soulard, N. A Comparison of North American surface temperature and temperature extreme anomalies in association with various atmospheric teleconnection patterns. Atmosphere 2019, 10, 172. [CrossRef]

7. Myoung, B.; Yeh, S.-W.; Kim, J.; Kafatos, M.C. Impacts of Pacific SSTs on atmospheric circulations leading to California winter precipitation variability: A diagnostic modeling. Atmosphere 2018, 9, 455. [CrossRef]

8. Ye, X.; Wu, Z. Contrasting impacts of ENSO on the interannual variations of summer runoff between the upper and mid-lower reaches of the Yangtze River. Atmosphere 2018, 9, 478. [CrossRef]

9. Fan, L.; Xu, J.; Han, L. Impacts of onset time of El Niño events on summer rainfall over Southeastern Australia during 1980-2017. Atmosphere 2019, 10, 139. [CrossRef]

10. Hou, X.; Cheng, J.; Hu, S.; Feng, G. Interdecadal variations in the walker circulation and its connection to inhomogeneous air temperature changes from 1961-2012. Atmosphere 2018, 9, 469. [CrossRef]

11. Huang, K.; Ren, H.-L.; Liu, X.; Ren, P.; Wei, Y.; Mu, M. Parameter modulation of Madden-Julian Oscillation behaviors in BCC_CSM1.2: The key role of moisture-shallow convection feedback. Atmosphere 2019, 10, 241. [CrossRef]

12. Ning, L.; Liu, J.; Wang, B.; Chen, K.; Yan, M.; Jin, C.; Wang, Q. Variability and mechanisms of megadroughts over Eastern China during the Last Millennium: A model study. Atmosphere 2019, 10, 7. [CrossRef]

13. Chen, S.; Yu, B.; Chen, W.; Wu, R. A Review of atmosphere-ocean forcings outside the Tropical Pacific on the El Niño-Southern Oscillation occurrence. Atmosphere 2018, 9, 439. [CrossRef]

14. Zhang, H.; Zhou, X.; Zou, J.; Wang, W.; Xue, L.; Ding, Q.; Wang, X.; Zhang, N.; Ding, A.; Sun, J.; et al. A Review on the methods for observing the substance and energy exchange between atmosphere boundary layer and free troposphere. Atmosphere 2018, 9, 460. [CrossRef]

(C) 2019 by the authors. Licensee MDPI, Basel, Switzerland. This article is an open access article distributed under the terms and conditions of the Creative Commons Attribution (CC BY) license (http://creativecommons.org/licenses/by/4.0/). 